\title{
Tension pneumothorax and pneumoperitoneum after double-lumen endotracheal intubation
}

\author{
Matthijs M den Os, Manouk Vermeulen, Dick Naafs, Lenneke E M Haas
}

\begin{abstract}
- Additional material is published online only. To view please visit the journal online (http://dx.doi.org/10.1136 bcr-2017-223275).
\end{abstract}

Intensive Care, Diakonessenhuis Utrecht, Utrecht, The Netherlands

\section{Correspondence to Lenneke E M Haas, \\ |vlelyveld@diakhuis.nl}

Accepted 19 November 2017

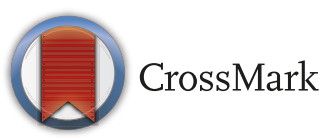

To cite: den Os MM, Vermeulen M, Naafs D, et al. BMJ Case Rep Published Online First: [please include Day Month Year]. doi:10.1136/bcr-2017223275

\section{DESCRIPTION}

A 75-year-old woman with a history of hypertension was admitted to our hospital for video-assisted thoracic surgery of the right caudal lung lobe because of a pT4N0M0 adenocarcinoma. After uneventful induction of anaesthesia, a difficult intubation was encountered due to a short stature and limited mobility of the neck. After multiple attempts a 35 French double-lumen tube was placed over a gum-elastic bougie with help of a video laryngoscope. To confirm correct placement a bronchoscopy was performed; however, the carina could not be visualised and the tube was repositioned several times.

Suddenly a swelling of the abdomen and subcutaneous emphysema in the neck were noticed, ventilation pressures increased, and the patient developed bradycardia. A tension pneumothorax was suspected and bilateral needle thoracentesis was performed. The double-lumen tube was replaced by a size 6.5 single-lumen tube. Bilateral thorax drains were placed and the patient was admitted to the intensive care. Fibreoptic bronchoscopy revealed no tear of the trachea and an oesophagoscopy was unremarkable. A CT of the thorax and abdomen showed correct position of the thorax drains, massive pneumoperitoneum (figure 1), and diffuse subcutaneous and mediastinal emphysema (figure 2).

Ventilation became increasingly difficult on the intensive care with rapidly increasing driving

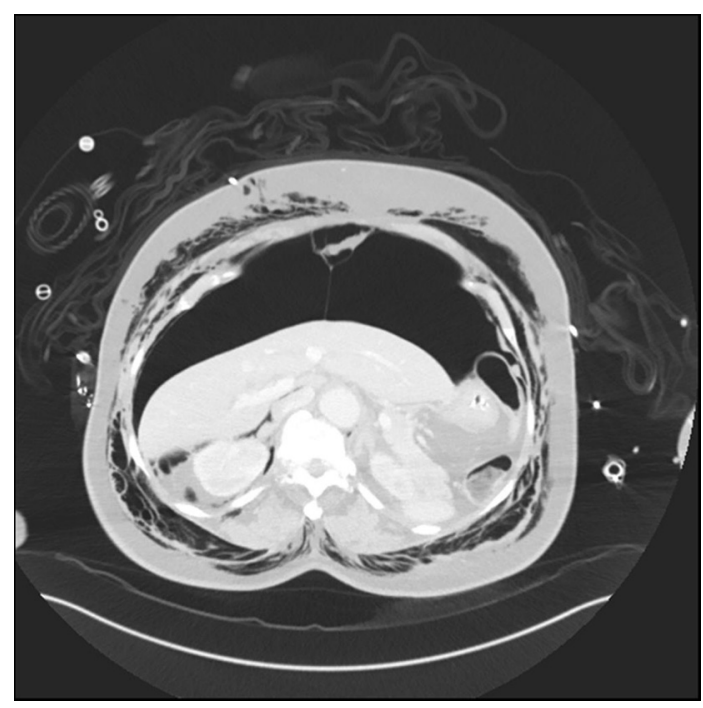

Figure 1 Axial cross-section of the abdomen showing free air in the peritoneum and air in the retroperitoneal space on the right. Pay special notice to the ligamentum falciforme clearly visible in this coupe.

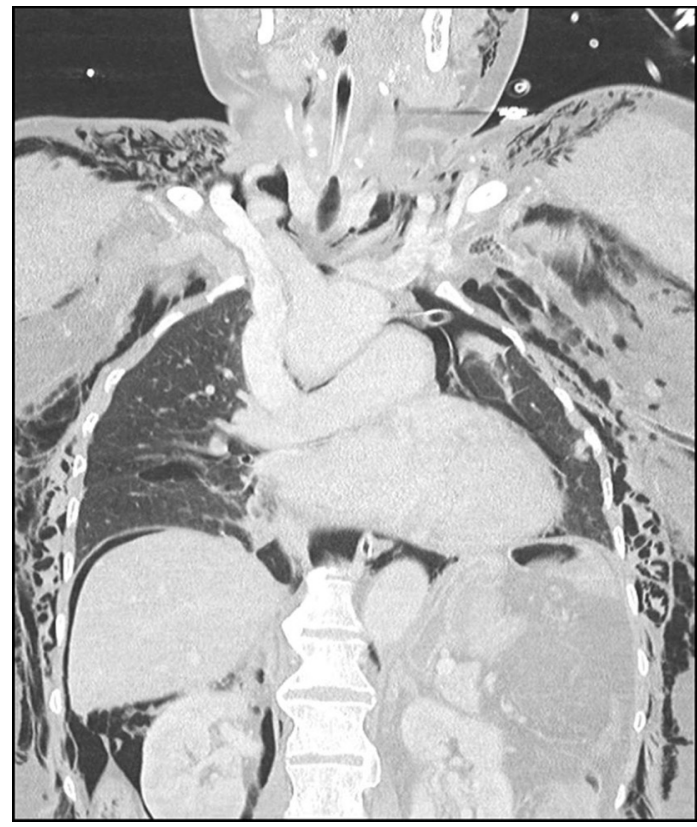

Figure 2 Coronal cross-section depicting free air above the liver, pneumothorax on the left side with a drain in situ and pneumomediastinum. Also there is ample subcutaneous emphysema all around the thorax, the neck and even around the jaw on the left.

pressures and concomitant haemodynamic instability. Clinical examination revealed a marked increase in abdominal distension compared with when the patient was admitted. We hypothesised that the pneumoperitoneum impeded our ability to properly ventilate. Nearly all case reports about combined pneumothorax and pneumoperitoneum are associated with a traumatic injury mechanism where surgery will be performed anyway to exclude intestinal perforation, thus resolving the pneumoperitoneum.

Since we did not suspect intestinal perforation, we decided to deflate the abdomen using an intramuscular needle (online supplementary video 1). After deflating the abdomen driving pressures dropped spectacularly and haemodynamic support could be withdrawn. Several days later the patient was successfully extubated. A culprit lesion was never found.

Tension pneumoperitoneum is a rare sequela of a tension pneumothorax. Numerous reports have been written about pneumothorax-associated pneumoperitoneum in combination with a diaphragm defect allowing air to directly enter the peritoneum. A second proposed mechanism is that as a result of high intrathoracic pressure, 


\section{Learning points}

- Tracheobronchial rupture is a rare but life-threatening complication of endotracheal intubation possibly associated with female sex and short stature. ${ }^{2}$

- Respiratory failure combined with haemodynamic instability was treated by deflating the pneumoperitoneum.

air escaping from ruptured alveoli, or in this case perhaps a trachea lesion, leaks into the mediastinum through the diaphragm openings into the retroperitoneum and peritoneum. ${ }^{1}$ Even though a culprit lesion was never found, this mechanism explains fully the development of pneumoperitoneum in our patient and the rapid improvement in clinical condition after abdominal deflation.
Contributors MMdO wrote the manuscript and collected the images under supervision of LEMH. MV coauthored the manuscript. DN reviewed all the CT imaging and helped select the most illustrative images. LEMH acquired informed consent and is the corresponding author.

Competing interests None declared.

Patient consent Obtained.

Provenance and peer review Not commissioned; externally peer reviewed.

(c) BMJ Publishing Group Ltd (unless otherwise stated in the text of the article) 2017. All rights reserved. No commercial use is permitted unless otherwise expressly granted.

\section{REFERENCES}

1 Zotos PG, Kontogiannis AG, Dimakopoulos AD, et al. Tension pneumoperitoneum in association with tension pneumothorax. Am J Respir Crit Care Med 2012;186:1306.

2 Miñambres E, González-Castro A, Burón J, et al. Management of postintubation tracheobronchial rupture: our experience and a review of the literature. Eur J Emerg Med 2007;14:177-9.

Copyright 2017 BMJ Publishing Group. All rights reserved. For permission to reuse any of this content visit

http://group.bmj.com/group/rights-licensing/permissions.

BMJ Case Report Fellows may re-use this article for personal use and teaching without any further permission.

Become a Fellow of BMJ Case Reports today and you can:

- Submit as many cases as you like

- Enjoy fast sympathetic peer review and rapid publication of accepted articles

- Access all the published articles

Re-use any of the published material for personal use and teaching without further permission

For information on Institutional Fellowships contact consortiasales@bmjgroup.com

Visit casereports.bmj.com for more articles like this and to become a Fellow 